\title{
A Review of Research Results on Stevia rebaudiana Bertoni in Yucatan Mexico from 2010 to 2017
}

\author{
Genovevo Ramírez-Jaramillo, Mónica Guadalupe Lozano-Contreras ${ }^{2 *}$, \\ Yolanda Beatriz Moguel-Ordoñez ${ }^{2}$, Wilson I. Aviles-Baeza², Jorge H. Ramírez-Silva1 \\ ${ }^{1}$ Centro de Investigación Regional Sureste del Instituto Nacional de Investigaciones Forestales, Agrícolas y Pecuarias (INIFAP), \\ Mérida, México \\ ${ }^{2}$ Campo Experimental Mocochá del Instituto Nacional de Investigaciones Forestales, Agrícolas y Pecuarias (INIFAP), Mocochá, \\ México \\ Email: *lozano.monica@inifap.gob.mx
}

How to cite this paper: Ramírez-Jaramillo, G., Lozano-Contreras, M.G., Moguel-Ordoñez, Y.B., Aviles-Baeza, W.I. and Ramírez-Silva, J.H. (2021) A Review of Research Results on Stevia rebaudiana Bertoni in Yucatan Mexico from 2010 to 2017. Open Access Library Journal, 8: e8164.

https://doi.org/10.4236/oalib.1108164

Received: November 8, 2021

Accepted: December 18, 2021

Published: December 21, 2021

Copyright $\odot 2021$ by author(s) and Open Access Library Inc.

This work is licensed under the Creative Commons Attribution International License (CC BY 4.0).

http://creativecommons.org/licenses/by/4.0/

(c) (i) Open Access

\begin{abstract}
This paper integrates information on research studies carried out, in Stevia rebaudiana Bertoni, by the Southeast Regional Research Center (CIRSE) of the National Institute of Forestry, Agricultural and Livestock Research (INIFAP) in Mexico. Stevia is an ancient plant of Paraguayan origin with great potential to produce natural sweeteners. There is a constant demand at the national and international levels for this crop so new varieties adapted to different environments are required in order to reduce production costs, avoid dependence from abroad, improve yields and increase the acreage. The Mexican CIRSE has documented a series of innovations since 2010 in stevia such as: 1) studies of the productive potential, 2) production of seedlings with biological rooters, 3) population densities, 4) pre-emergence control of weeds, 5) fertilization doses, 6) materials better adapted to Mexican environment conditions and 7) evaluation of main stevia glycosides such as Stevioside and Rebaudioside- $A$ among the most important. The main scientific findings are reported in this paper with the hope that stevia producers use it as a guide to improving their stevia production crop.
\end{abstract}

\section{Subject Areas}

Agricultural Engineering

\section{Keywords}

Innovations, Sweetener, Ka' a He’ë(Sweet Herb), Tropic of Mexico 


\section{Introduction}

Stevia is a native plant from the Amambay mountain range located between southern Brazil and northern Paraguay [1] [2], This is a region where the original Guaraní people are located and the plant is known as Kà a Hëë (sweet herb) which has been used for centuries, for the Guarani tribes of Paraguay and Brazil as sweetener to counteract the bitter taste of medicines and in yerba mate tea. It is also used as medicinal infusions to treat stomach acidity, glycemic regulation and hypertension [3] [4] [5] [6] [7]. It is a species of the Asteraceae family (formerly Compositae); and it is a perennial herb that can reach $100 \mathrm{~cm}$ high [8].

Japan was the first country to accept the use of Stevia and it is being used for more than 40 years [9] as dried leaves and using the active and pure steviosides to replace cyclamate and saccharin in more than $40 \%$ of the sweetener market [10]. The commercial blockade during the Second World War and the high international price of sugar forced the Japanese to look for new sweetener alternatives [11]. They discovered the active ingredients and their attributes when chemically analyzing the Stevia; since then, approximately $50 \%$ of the sweetener market has been substituted by Stevia [12]. The commercial exploitation of Stevia has increased significantly since 1970, when Japanese researchers developed a series of protocols for the extraction and purification of the sweetening compounds in the plant [13] [14].

Despite the fact that stevia began to be produced by Japan in 1970, in Mexico its cultivation started in 2010 with an increasing interest by local farmers. According to data from the Agrifood and Fisheries Information Service (SIAP) stevia was officially reported by the Mexican government in 2012 [15].

Stevia was first introduced to Mexico in 2010 through the National Institute of Forestry, Agricultural and livestock Research (INIFAP) in order to study its adaptability. The best areas found with good production potential were the states of Chiapas, Yucatán, Quintana Roo, Campeche, Veracruz and Nayarit according to CIRSE [15].

Stevia cultivation is an innovative and very profitable alternative [16]. However, in Mexico, at the beginning of its development the average yields obtained were not economically feasible for farmers [16]. In 2010, agronomic research was practically negligible so technological information was highly needed [17].

In order to face the problem of lack of information the National Institute of Forestry, Agricultural and Livestock Research (INIFAP) launched different investigation strategies related to: studies on productive potential, optimal population densities, production under irrigation conditions, weed control, nutritional requirements, soil fertilization, content of Stevíoside and Rebaudíosido-A in different materials and profitability analysis under Yucatán conditions in México [17].

During these last nine years, specific results have emerged such as: Development and Technological Diffusion of Stevia under Irrigation Conditions, Production of Stevia seedlings by using biological rooters, Genetic improvement to 
produce clonal varieties, weed control in early stages and economic profitability by integrating all the above mentioned technologies.

Even though the existing research results, developed throughout these nine years in Mexico, it is still important to keep searching for new technological innovations capable to incentivize farmers to produce stevia with more high profitability. This paper documents the technological innovations generated by the Southeast Regional Research Center of INIFAP in Mexico in order to share an important research background for future research programs.

\section{Materials and Methods}

This work was carried out at the Southeast Regional Research Center (CIRSE) of the National Institute of Forestry, Agricultural and Livestock Research (INIFAP) with the headquarters located in the City of Mérida, Yucatán, Mexico.

A documentary research was carried out in order to select, compile, organize, interpret and analyze information of the main projects that have been conducted in the state of Yucatan Mexico; and the main technological innovations are to be mentioned.

This kind of research has become, in a short space of time, in technique which can include different matters from manual to mechanical processes [18]. Following are mentioned the most important characteristics of the documentary research:

- It is common to all types of research with a theoretical or referential foundation, being natural or social sciences

- It obtains data from reviewed documents of different areas

- It organizes the collected data consistently

- It allows to rediscover or reinterpret different aspects of a subject

- It helps to identify gaps, omissions or misrepresentations from reference sources

- It suggests new perspectives and/or analytical theories based on the information obtained

- It requires the ability for synthesis, deduction and analysis

- It provides strength to the researcher's conclusions

For documentary research, in a strategic sense, there are two types of essential sources: The Primary Research sources and the Secondary ones. For this work the following sources of information were considered:

Primary research sources gave us the first-hand, original and relevant information. For this case, the projects related to the cultivation of Stevia and their corresponding reports from 2010 to 2021 were considered as Primary sources [18].

Secondary research sources were considered all information gathered from other sources which were submitted to a process of scrutiny, restructuring, analysis, and criticism. The secondary sources would be other previous biographies or history books that expose at least part of the theme under study. Printed or 
digital documents from conferences, symposia or publicity information were considered Secondary sources [18].

Based on the information from the primary and secondary sources, basic information of projects that were carried out from 2010 to 2021 at CIRSE and their main contributions are presented in Table 1. Details of each projct will be described later on.

\section{Results and Discussion}

\section{Projects Description}

Project 1. Validation, development and technological dissemination in Stevia (Stevia rebaudiana Bertoni) under irrigation conditions in south-southeast Mexico.

Subproject 1.1: Determination of the productive potential of Stevia rebaudiana Bertoni in Mexico.

Contribution 1.1.1. There is a continuous demand for stevia at national and international level but due to the scarcity of raw material the Mexican government, industrials, private and social sectors are highly interested in its cultivation. To do so, better decision-making is needed and the best potential areas are to be selected.

Table 1. Projects of Stevia rebaudiana Bertoni which were carried out from 2010 to 2017 in CIRSE-INIFAP.

\begin{tabular}{|c|c|c|c|c|}
\hline Project Names & $\begin{array}{l}\text { Type of Project and } \\
\text { Researcher in charge }\end{array}$ & Period & $\begin{array}{l}\text { Funds }(\$) \text { in } \\
\text { Mexican pesos }\end{array}$ & Results \\
\hline $\begin{array}{l}\text { Validation, Development and } \\
\text { Technology Dissemination of } \\
\text { Stevia (Stevia rebaudiana Bertoni) } \\
\text { under Irrigation Conditions in } \\
\text { South-Southeast Mexico. }\end{array}$ & $\begin{array}{l}\text { Basic and Applied Research } \\
\text { Ramírez Jaramillo Genovevo }\end{array}$ & 2010 to 2012 & $1,200,000.00$ & $\begin{array}{l}\text { 1) Pre-emergent Weed Control } \\
\text { 2) Population density to reduce } \\
\text { costs } \\
\text { 3) Determination of glycoside } \\
\text { content in leaves } \\
\text { 4) Potential areas for stevia } \\
\text { cultivation in Mexico } \\
\text { 5) Technological Validation in } \\
\text { four states of South-Southeast } \\
\text { Mexico }\end{array}$ \\
\hline
\end{tabular}

Research, Development, Promotion and Technology Transfer for the use of biofertilizers in different agro-ecological environments.
Applied research Lozano Contreras Mónica 2010 to $2012 \quad 250,000.00 \quad$ 1) Biological rooters for stevia Guadalupe seedlings

\begin{tabular}{|c|c|c|c|c|}
\hline Stevia Seedling Production & $\begin{array}{c}\text { Applied research } \\
\text { Ramírez Jaramillo Genovevo }\end{array}$ & 2012 to 2014 & $300,000.00$ & $\begin{array}{l}\text { 1) Protocol for stevia seedlings } \\
\text { production }\end{array}$ \\
\hline $\begin{array}{l}\text { Genetic breedings of stevia (Stevia } \\
\text { rebaudiana Bertoni) to obtain } \\
\text { Mexican clonal varieties }\end{array}$ & $\begin{array}{c}\text { Applied research } \\
\text { Ramírez Jaramillo Genovevo }\end{array}$ & 2015 to 2017 & $300,000.00$ & 1) Lot of clonal varieties \\
\hline $\begin{array}{l}\text { Characterization of genetic materials } \\
\text { of Stevia rebaudiana Bertoni. }\end{array}$ & $\begin{array}{c}\text { Applied research } \\
\text { Ramírez Jaramillo Genovevo }\end{array}$ & 2017 & $200,000.00$ & $\begin{array}{l}\text { 1) Characterization of an } \\
\text { outstanding material }\end{array}$ \\
\hline
\end{tabular}


INIFAP has databases in *.shp format about soils, climate types, precipitation, temperature and altitude and the agroecological requirements of the crop. This information was used to reclassify the areas in suboptimal and optimal conditions using the Arc/View 3.3 software. In Mexico there are more than 3 million hectares with optimal condition and more than 2 million with suboptimal ones with a geographical distribution according to Figure 1. It is feasible to increase the surface and the productivity of stevia cultivation mainly in the Pacific, Gulf and in the Yucatan Peninsula [19] [20] [21] [22] [23].

More than 13 states of the Mexican Republic were identified with optimal conditions and more than 14 states showed to be in a suboptimal environment to produce stevia under irrigation. The key factors to classify high potential areas were: altitude, temperature and type of soil.

Subproject 1.2. Weed control to establish Stevia rebaudiana Bertoni, in Yucatan, Mexico.

Contribution 1.2.1: The high labor demand for weed control represents important increases in the production costs. Profitability is reduced when there is a lack of hand laborers. This study aimed to evaluate other alternatives for weed control to reduce the dependence on labor trying to avoid the contamination of the harvested leaves.

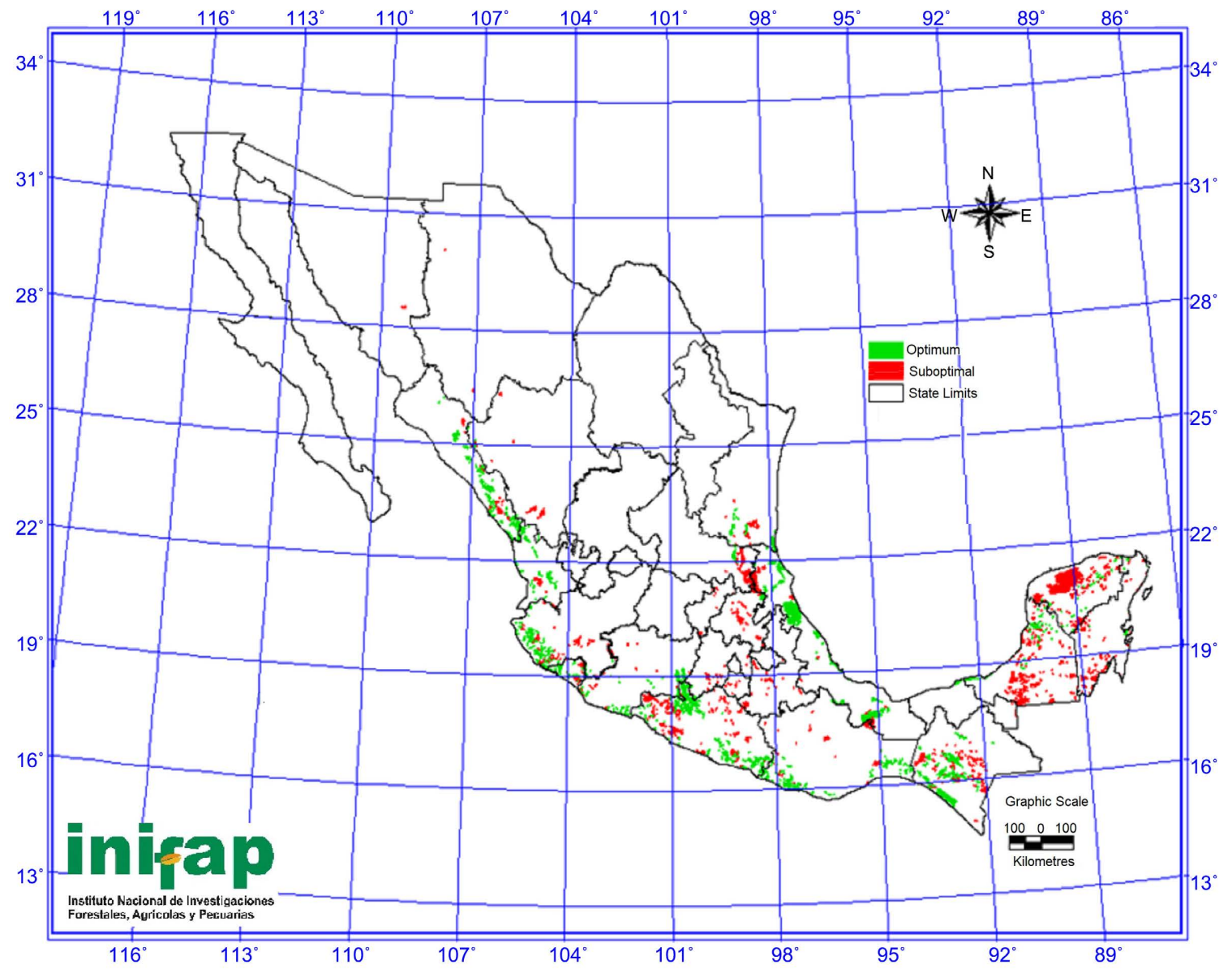

Figure 1. Geographical distribution of potential areas for stevia cultivation in Mexico. 
The Trifuralin herbicide and their effect on weed control were evaluated at three different doses at first stage of stevia production in a red deep Luvisol and a stony rendzic Leptosol in Muna and Mocochá, Yucatan Mexico.

The weed cover was recorded 18 and 35 days after the application (DAA) of Trifluralin in both localities (Table 2). High Variation Coefficients (VC) were found ranging from $120 \%$ to $186 \%$. However, when analyzing the numerical values it was evident that the herbicide was highly effective to control weeds in both localities.

In Mocochá, weeds were reduced from $43.76 \%$ (T1) to $93.50 \%$ (T2 and T3) at 18 DAA and from $62.7 \%$ (T1) to $88.72 \%$ (T2) and $91.75 \%$ (T3) at 35 DAA. In Muna the weed reduction was more drastic, even with the lower dose of Trifluralin. This was probably due to the fact that the deep red soil favored a more homogeneous dispersion of the herbicide on the surface. Weed cover was reduced above $95 \%$ in Muna.

Subproject 1.3. Population density for the establishment of Stevia rebaudiana Bertoni in Yucatan, Mexico

Contribution 1.3.1: At the beginning when stevia was introduced in Mexico, a high plant density of 100 to 200 thousand seedlings per hectare was recommended. However, high densities favored the incidence of fungal diseases and the production cost increased due to high seedling prices in the market (2.00 to 5.00 Mexican pesos per seedling).

With the new technology, INIFAP proposed to farmers, a new population density ranging from 58,000 to 60,000 plants per hectare, planting the seedlings, in triangle position, at $40 \mathrm{~cm}$ distance each other on beds of 1-meter-wide and 50 meters long.

Four crop lines on each bed are recommended to be irrigated with two irrigation strips and droppers every 25 to 30 centimeters. Transplanting 250 plants per row and 1000 plants in the 4 rows producers can reduce the population density, the production cost diminishes by up to $33.8 \%$ and the Benefit/Cost ratio ranges from 2.27 to 2.90 [12] [24] (Figure 2).

Table 2. Weed cover (\%) and herbicide effect (\% of reduction) in a stevia crop. Application of Trifluralin in two localities of Yucatan, Mexico.

\begin{tabular}{|c|c|c|c|c|c|c|c|c|}
\hline \multirow[b]{2}{*}{ Treatments } & \multicolumn{4}{|c|}{ Mocochá } & \multicolumn{4}{|c|}{ Muna } \\
\hline & $\begin{array}{c}18 \\
\text { DAA }\end{array}$ & $\begin{array}{l}\% \text { of } \\
\text { Red. }\end{array}$ & $\begin{array}{c}35 \\
\text { DAA }\end{array}$ & $\begin{array}{l}\% \text { of } \\
\text { Red. }\end{array}$ & $\begin{array}{c}18 \\
\text { DAA }\end{array}$ & $\begin{array}{l}\% \text { of } \\
\text { Red. }\end{array}$ & $\begin{array}{c}35 \\
\text { DAA }\end{array}$ & $\begin{array}{l}\text { \% of } \\
\text { Red. }\end{array}$ \\
\hline $\begin{array}{l}\text { T0 (Control) } \\
(0 \mathrm{ml} \text { of c.m./l) }\end{array}$ & $7.70 \mathrm{NS}$ & --- & $\begin{array}{c}24.75 \\
\text { NS }\end{array}$ & & $\begin{array}{l}7.88 \\
\text { NS }\end{array}$ & & $\begin{array}{c}46.25 \\
\text { NS }\end{array}$ & \\
\hline $\mathrm{T} 1$ (5 ml of c.m./l) & 4.33 & 43.76 & 9.21 & 62.78 & 0.06 & 99.23 & 2.25 & 95.13 \\
\hline $\mathrm{T} 2(7.5 \mathrm{ml}$ of $\mathrm{c} . \mathrm{m} . / \mathrm{l})$ & 0.50 & 93.50 & 2.79 & 88.72 & 0.15 & 98.09 & 1.00 & 97.83 \\
\hline T3 (10 ml de c.m./l) & 0.50 & 93.50 & 0.75 & 91.75 & 0.07 & 99.11 & 1.27 & 97.25 \\
\hline VC (\%) & 122.41 & & 121.92 & ---- & 186.53 & ----- & 130.68 & ----- \\
\hline
\end{tabular}

c.m./l = Commercial Material per liter of water. NS $=$ No Significant Differences. $\mathrm{DAA}=$ Days After Application. 


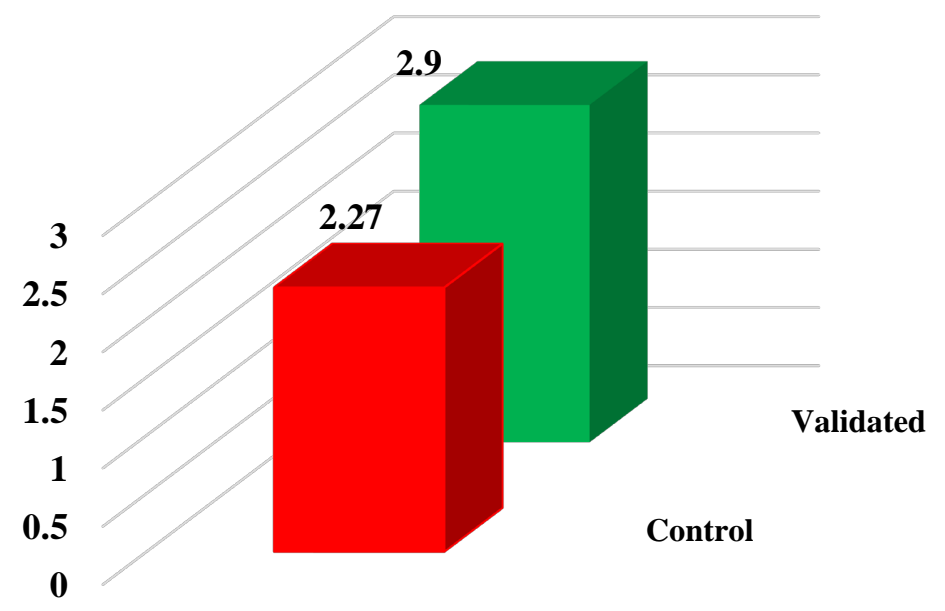

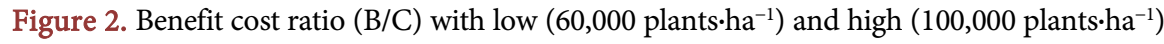
population densities.

Subproject 1.4. Validation of technology on Stevia rebaudiana (Bertoni), in the South-Southeast of Mexico under irrigation conditions.

Contribution 1.4.1: At international level there are outstanding countries such as Colombia and Peru with proper technologies to grow stevia and Peru with high yields of 7.0 to $8.0 \mathrm{t}^{\mathrm{th}} \mathrm{h}^{-1}$ of dry leaves under irrigation conditions while Paraguay does not exceed 3 or $4 \mathrm{t} \cdot \mathrm{ha}^{-1}$ under irrigation and 1.0 or $2.0 \mathrm{t} \cdot \mathrm{ha}^{-1}$ under rainforest.

In order to promote new technologies to private companies, interested on stevia cultivation and industrialization, it was basic to validate the existing INIFAP technology in plots of cooperating companies. The validation was carried out in the South-Southeast region of Mexico in 5 plots scattered in the states of Yucatán (2), Quintana Roo (1), Chiapas (1) and Veracruz (1). There are private companies in those states highly interested to cultivate, industrialize and commercialize stevia [12] [25]-[30].

The results have shown that stevia is well adapted to the Yucatan climate and soils conditions. In 2011, yield at first harvest was $3.54 \mathrm{t}^{\mathrm{ha}} \mathrm{h}^{-1}$ in stony soils (Leptosols) of Baca and $4.23 \mathrm{t} \cdot \mathrm{ha}^{-1}$ in the Luvisols of Tizimín both localities in the state of Yucatán, Mexico.

The plant height in Tizimín was $48 \mathrm{~cm}$ while in Baca $46 \mathrm{~cm}$; the canopy diameter in Tizimín was $46 \mathrm{~cm}$ in Tizimín and $41 \mathrm{~cm}$ in Baca. So based on the validation results it can be concluded that Yucatán has good production potential for stevia crop.

Subproject 1.5. Content of Stevioside and Rebaudioside A, in three materials of Stevia rebaudiana Bertoni cultivated in the South-Southeast of Mexico

Contribution 1.5.1: This work aimed to evaluate the content of Stevioside and Rebaudióside A in leaves of Stevia diverse genetic materials established in South-Southeast Mexico.

Four genetic materials from Paraguay were evaluated in the state of Quintana 
Roo, Mexico: three creoles (creol 1, Paraguayan Creol and the SM1) and one genetic improved material named Morita II.

Morita II was evaluated in the states of Yucatán, Quintana Roo, Veracruz and Chiapas. Approximately $1 \mathrm{~kg}$ of leaves were cut 3 months after planting and the content of Stevioside and Rebaudioside A were quantified using a liquid chromatography (HPLC).

There were found statistical differences $(\mathrm{P}<0.05)$ in the content of sweeteners between the studied materials. The concentration of Stevioside for Creol 1, Paraguayan Creol, SM1 and Morita II were 7.15c $\pm 0.70,5.09 \mathrm{~b} \pm 0.04,5.03 \mathrm{~b} \pm 0.10$ and $1.92 \mathrm{c} \pm 0.43$ grams per each 100 grams of dry leaves; and the concentrations of $R e$ baudioside A were $2.93 \mathrm{~b} \pm 0.27,2.42 \mathrm{~b} \pm 0.08,1.72 \mathrm{a} \pm 0.09$ and $10.12 \mathrm{a} \pm 2.11$ grams per $100 \mathrm{~g}$ respectively. No significant statistical differences $(\mathrm{P}>0.05)$ were found between the Glycoside content of Morita II established in the different states.

The Stevioside was the glycoside with higher concentration in all materials with the exception of Morita II (Table 3). This material showed different behavior as compared to the other materials since it presented a higher concentration of Rebaudioside A. This is an advantage due to the fact that Rebaudioside A is less bitter and sweeter than Stevioside. Morita II is a material with great potential for the sweetener industry [21] [22] [31].

Project 2. Research, Development, Promotion and Technological Transfer for the use of Bio-fertilizers in Different Agroecological Environments.

Subproject 2.1. Biological rooters for the production of stevia seedlings.

Contribution 2.1.1. Conventionally, to favor the rooting of stevia cuttings, commercial products based on hormones (auxins) are applied such as in-dolbutyric and naphthalene acetic acids. Another better option is the application of beneficial microorganisms, such as Mycorrhizae and bacteria such as Azospirillum or Bacillus, which act as biological rooters.

Beneficial microorganisms improve plant development and nutrition and increase crop tolerance to biotic or abiotic stress. The interest in the use of $M y$ corrhizae and bacteria is due to a positive symbiosis effect, since Mycorrhiza increases the absorption of nutrients when water absorption is improved and at

Table 3. Estevioside and Rebaudioside $A$ content in four stevia materials.

\begin{tabular}{ccc}
\hline & Estevioside & Rebaudioside $A$ \\
\cline { 2 - 3 } Material & \multicolumn{2}{c}{$\begin{array}{c}\text { g/100 g of dry leaves } \\
\text { Average } \pm \text { Standard deviation }\end{array}$} \\
\hline Creol & $7.15 \mathrm{a} \pm 0.70$ & $2.93 \mathrm{~b} \pm 0.27$ \\
Paraguayan Creol & $5.09 \mathrm{~b} \pm 0.04$ & $2.42 \mathrm{~b} \pm 0.08$ \\
SM1 & $5.03 \mathrm{~b} \pm 0.10$ & $1.72 \mathrm{~b} \pm 0.09$ \\
Morita II & $1.92 \mathrm{c} \pm 0.43$ & $10.12 \mathrm{a} \pm 2.11$ \\
\hline
\end{tabular}

a,b,c different letters in the same column indicate significant statistical differences. 
the same time avoids pathogens whilst bacteria produce growth stimulating phytohormones such as in-doleacetic acid, indole butyric acid and biologically fixes of gaseous nitrogen in a natural way.

To improve inoculation in the stevia cuttings, 15 grams of Mycorrhiza Rhizophagus intraradices or the mixture of Bacillus sp. and Azospirillum brasilienses should be mixed and stirred in 1 litter of water until having a homogeneous solution. The cuttings need 1 minute to be soaked in the solution before transplanting. Prolonged exposure in the solution can cause damage and failure of the rooting [32].

\section{Project 3. Production of Stevia Seedlings}

\section{Subproject 3.1. The protocol to produce stevia seedlings}

Contribution 3.1.1. A proper rooting of stevia is needed during plant production for future transplantation in the field. So, special care must be taken when handling the cuttings in the production trays. It is basic to remove some pairs of leaves and keep at least two internodes and three to four pairs of leaves. The proper length proposed is of approximately 8 centimeters after eliminating the lower parts of the cuttings. These are the parts that first enter into a negative oxidation process avoiding an optimal rooting. It is important that the plants, after being inoculated with biofertilizers (Mycorrhiza Rhizophagus intraradices or the mixture of Bacillus sp. and Azospirillum brasilienses), are placed on the trays (200 cavities) in a time no longer than 4 hours to avoid dehydration. The optimal depth of planting should be between 2.5 to $3.0 \mathrm{~cm}$ (Figure 3). It is important to compact, by pressing a little, the commercial rooting substrate in the trays and leaves should not be in contact with the substrate due to fungal diseases [21] [33].

Project 4. Genetic Improvement of Stevia (Stevia rebaudiana Bertoni) to Obtain Mexican Clonal Varieties

\section{Subproject 4.1. Clonal Varieties in Yucatán}

Contribution 4.1.1. Ten stevia materials with good phenotypic characteristics were studied, produced and selected since 2012. Just two out of the ten materials showed outstanding agronomic behaviour.

Project 5. Project: Characterization of Genetic Materials of Stevia rebaudiana Bertoni.

\section{Subproject 5.1. Characterization of Two Clonal Varieties}

Contribution 5.1.1. The characterization of a new clonal variety named in maya terms Ch'ujuk (Sweety) [34] [35] was obtained. The main characteristics are mentioned below.

Plant Height. Ch'ujuk is a clonal variety with an intermediate cycle (80 to 100 days), semi-decumbent plant with $10 \%$ to $70 \%$ of the stems in contact with the ground, average height of $60 \mathrm{~cm}$ as compared to the control Morita II with 45 $\mathrm{cm}$ (Figure 4). It is resistant to lodging since it is a multi-stem plant with abundant roots in relation to Morita II with a single stem, scarce root development and more susceptible to lodging and soil fungi deseases [36]. 


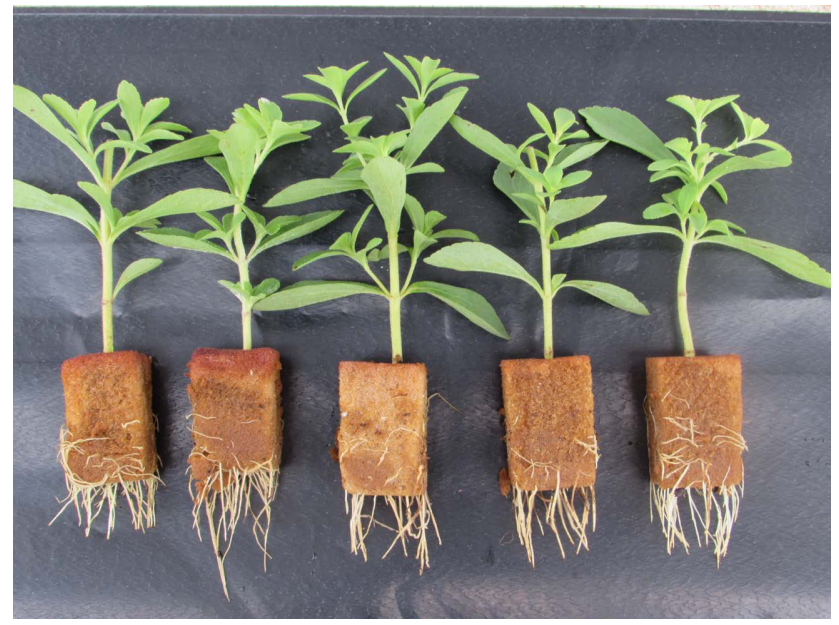

Figure 3. A 25 days old seedling ready to be transplanted.

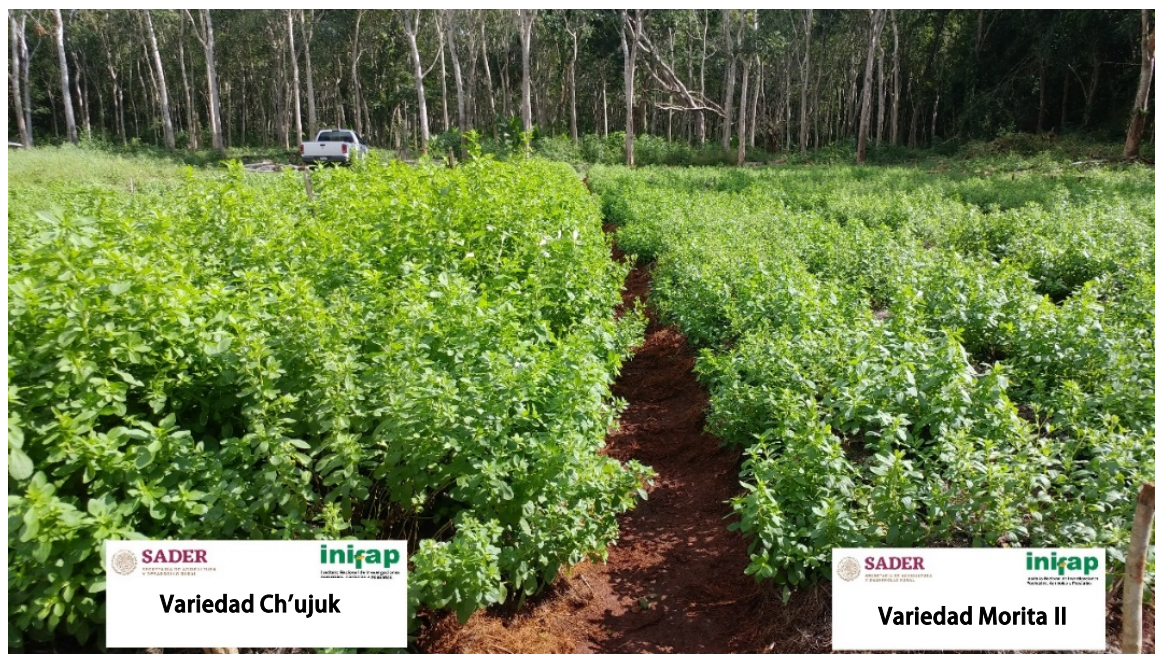

Figure 4. The Ch'ujuk clonal variety is $20 \mathrm{~cm}$ higher than Morita II.

Stem type and characteristics. It has above eight primary stems while Morita II only has three. Regarding secondary stems, the Ch'ujuk clone is highly branched (Figure 5) as compared to Morita II with little branching stems. The stem diameter is $15.9 \mathrm{~mm}$ against 8.39 for Morita II; although the internode length is a little bit greater in Morita II $(8 \mathrm{~cm})$ than that of the clone $(7 \mathrm{~cm})$ [36].

Leaf type and characteristics. An important factor in the yield of the "stevia" is the leaves. The average length of the leaves of Ch'ujuk is $6 \mathrm{~cm}$ against the 4.5 $\mathrm{cm}$ of Morita II. In the case of the width, Ch'ujuk showed to have a $3 \mathrm{~cm}$ wide leaves and Morita II just $1.5 \mathrm{~cm}$ and the petioles are sessile in both varieties. The margins of the blades, with 12 teeth, are crenate in Ch'ujuk while Morita II has serrate margins with 18 teeth. All leaves are in opposite position through the stems in all cases [36].

Inflorescence color. The color of the inflorescence is white [36].

Crop cycle of the Clonal Variety Ch'ujuk. The clonal variety has a short cycle (80 to 100 days) while Morita II has an intermediate one (100 to 130 days). 


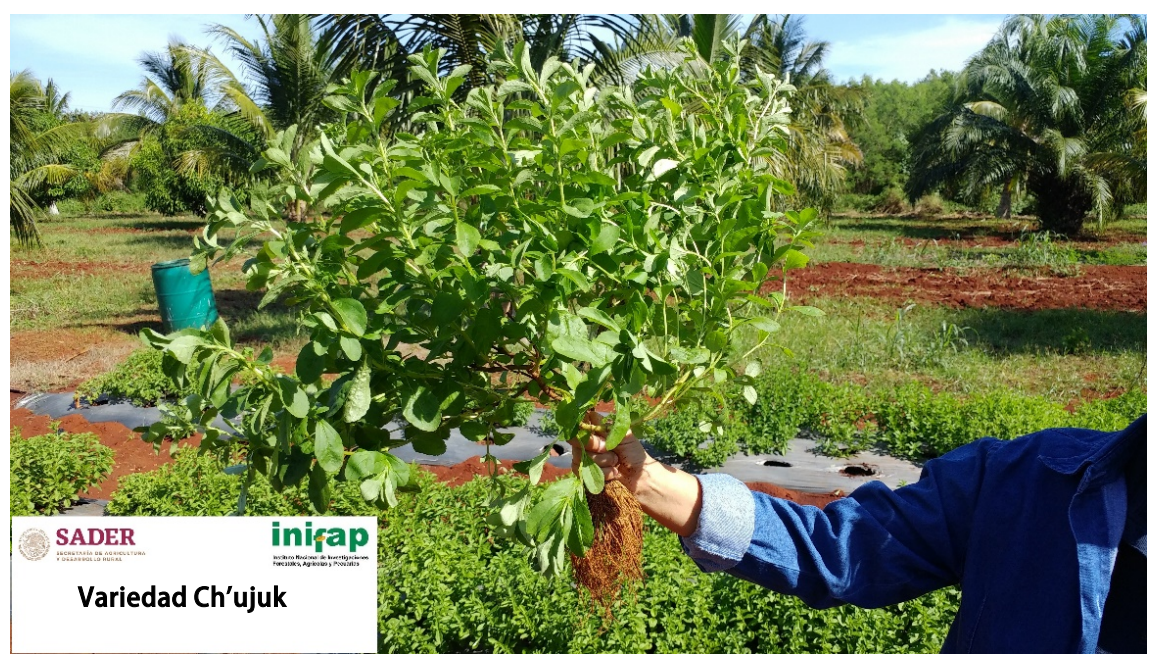

Figure 5. Ch'ujuk variety presents $6 \mathrm{~cm}$ long leaves with multi-stems and abundant roots.

This is an advantage of Ch'ujuk over Morita II since it can be harvested up to six times per year [36].

Sanitary Behavior. The Ch'ujuk clone has a moderate resistance to the fungi: Rhizoctonia solani, Fusarium sp and Sclerotium rolfsii and Morita II is moderately susceptible to Alternaria sp., Septoria sp. and Cercospora sp. [36].

Concentration of Glycosides. The concentration of the main glycosides measured in the clonal variety was $6.78 \mathrm{~g}$ of Stevioside per $100 \mathrm{~g}$ of dry leaves, $7.46 \mathrm{~g}$ of Rebaudioside- $A$ per $100 \mathrm{~g}$ of dry leaves and $2.14 \mathrm{~g}$ of Rebaudioside- $C$ per $100 \mathrm{~g}$ of dry leaves whilst for Morita II the numbers were 3.97, 14.5 and 2.24 g per $100 \mathrm{~g}$ of dry leaves of Stevioside, Rebaudioside- $A$ and Rebaudiósido-C respectively [36].

Yield Performance. The clonal variety showed a potential yield of $9.67 \mathrm{t} \cdot \mathrm{ha}^{-1}$ of dry leaves per year representing $0.73 \mathrm{t} \cdot \mathrm{ha}^{-1}$ of Rebaudioside- $A, 0.65 \mathrm{t} \cdot \mathrm{ha}^{-1}$ of Stevioside and $0.20 \mathrm{t} \cdot \mathrm{ha}^{-1}$ of Rebaudioside-C [36].

\section{Conclusions}

The Mexican CIRSE-INIFAP has technological innovations able to impact stevia production in Mexico. Potential zones have been defined where the largest areas are located in the states of the Pacific from Nayarit to Chiapas.

The technology referred to population density (plants per hectare) can balance the profitability in favor of the producers besides the advantage of having a clonal variety named Ch'ujuk well adapted to the agroclimatic conditions of the country including the tropics. The clonal variety Ch'ujuk is a good alternative for cultivation since it has shown better agronomic behavior and yield potential than the control Morita II.

In addition, the clonal variety Ch'ujuk presented an adequate balance between Stevioside and Rebaudioside- $A$ making it attractive for the sweetener industry and for direct consumption for health purposes.

The yield of dry leaves obtained with the clon was 1.7 times higher (9.67 
$\left.\mathrm{t} \cdot \mathrm{ha}^{-1}\right)$ than that of the Morita II $\left(3.5 \mathrm{t} \cdot \mathrm{ha}^{-1}\right)$. This new variety is recommended for the states of the Yucatan Peninsula in Mexico such as: Campeche, Quintana Roo and Yucatán; although, there are other states, located in the tropics, with great potential like: Nayarit, Michoacán, Jalisco, Guerrero, Oaxaca, Chiapas, Veracruz and Tabasco.

\section{Acknowledgements}

We thank the National Institute of Forestry, Agricultural and Livestock Research (INIFAP), for financing this work as part of the project called: Caracterización de mate-riales geneticos de Stevia rebaudiana Bertoni. (Characterization of Genetic Materials of Stevia rebaudiana Bertoni). Project number "15233034015”.

\section{Conflicts of Interest}

The authors declare no conflicts of interest.

\section{References}

[1] Ramesh, K., Singh, V. and Megeji, N.W. (2006) Cultivation of Stevia [Stevia rebaudiana (Bert.) Bertoni]: Acomprehensive Review. Advances in Agronomy, 89, 137-177. https://doi.org/10.1016/S0065-2113(05)89003-0

[2] Jarma, A., Rengifo, T. and Araméndiz-Tatis, H. (2005) Aspectos fisiológicos de estevia (Stevia rebaudiana Bertoni) en el Caribe colombiano: I. Efecto de la radiación incidente sobre el área foliar y la distribución de biomasa. Agronomía Colombiana, 23, 207-216. https://www.redalyc.org/pdf/1803/180316955003.pdf

[3] Alonzo-Torres, M. (2007) Uso del Kaa Hee en la horticultura. En: Producción de hortalizas todo el año. Mod. IV. Producción de Kaa Hee, Provincia de Formosa, Argentina, $13 \mathrm{p}$.

[4] Bonilla, C.R., Sánchez, M.S. and Perlaza, D.F. (2007) Evaluación de métodos de propagación, fertilización nitrogenada y fenología de estevia en condiciones del Valle del Cauca. Acta Agronómica, 56, 131-134. http://www.scielo.org.co/scielo.php?pid=S0120-28122007000300004\&script=sci abs tract\&tlng=es

[5] Brandle, J.E. and Telmer, P.G. (2007) Steviol Glycoside Biosynthesis. Phytochemistry, 68, 1855-1863.

https://www.sciencedirect.com/science/article/pii/S0031942207000933 https://doi.org/10.1016/j.phytochem.2007.02.010

[6] Durán, A.S., Rodríguez, N.M.P., Cordón, A.K. and Record, C.J. (2012) Stevia (Stevia rebaudiana), Non-Caloric Natural Sweetener. Revista Chilena de Nutrición, 39, 203-206.

https://scielo.conicyt.cl/scielo.php?pid=S0717-75182012000400015\&script=sci artte xt\&tlng=en https://doi.org/10.4067/S0717-75182012000400015

[7] Pande, S.S. and Gupta, P. (2013) Plant Tissue Culture of Stevia rebaudiana (Bertoni): A Review. Journal of Pharmacognosy and Phytotherapy, 5, 26-33. https://academicjournals.org/article/article1379693327 Pande\%20and\%20Priyanka. pdf

[8] Landázuri, P.A. and Tigrero, J.O. (2009) Generalidades. In: Landázuri, P.A. and Tigrero, J.O., Eds., Stevia rebaudiana Bertoni, una planta medicinal, Boletín Técnico 
Edición Especial, ESPE, Sangolquí, Ecuador, 1-4.

[9] Sato, N. (2003) The Miracles and Mysteries of Stevia. The Anti-Oxidizing Plant. Seishun Shuppanasha, Tokyo.

[10] González-Moralejo, A.S. (2011) Aproximación a la comprensión de un endulzante natural alternativo, la Stevia rebaudiana Bertoni: Producción, Consumo y Demanda Potencial. Agroalimentaria, 17, 57-69.

https://riunet.upv.es/bitstream/handle/10251/59571/Andr\%c3\%a9s\%20-\%20Aproxim aci\%c3\%b3n\%20a\%20la\%20comprensi\%c3\%b3n\%20de\%20un\%20endulzante $\% 20$ nat ural\%20alternativo\%2c\%20la\%20Stevia\%20Rebaudiana....pdf?sequence=1\&isAllowed $=\mathrm{y}$

[11] Martínez, P.T. (2000) La Hierba Dulce, Historia, Usos y Cultivo de Stevia rebaudiana Bertoni. Ciencias de la Salud, Madrid, $125 \mathrm{p}$.

https://www.librosenred.com/libros/lahierbadulcehistoriausosycultivodelasteviareba udianabertoni.html

[12] Ramírez-Jaramillo, G. and Lozano-Contreras, M.G. (2017) La producción de Stevia rebaudiana Bertoni en México. Agroproductividad, 10, 84-90.

http://revista-agroproductividad.org/index.php/agroproductividad/article/view/108 $\underline{0 / 926}$

[13] Dacome, A.S., da Silva, C.C., da Costa, C.E.M., Fontana, J.D., Adelmann, J. and da Costa, S.C. (2005) Sweet Diterpenic Glycosides Balance of a New Cultivar of Stevia rebaudiana (Bert.) Bertoni: Isolation and Quantitative Distribution by Chromatographic, Spectroscopic, and Electrophoretic Methods. Process Biochemistry, 40, 3587-3594. https://doi.org/10.1016/j.procbio.2005.03.035

[14] González, C., Tapia, M.S., Pérez, E., Dornier, M. and Morel, G. (2014) Caracterización de cultivares de Stevia rebaudiana Bertoni de diferentes procedencias. Bioagro, 26, 79-88. https://www.redalyc.org/pdf/857/85731100002.pdf

[15] Centro de Estudios para el Desarrollo Rural Sustentable y la Soberanía Alimentaria (CEDRSSA) (2018) Oportunidades para la agricultura en México: La estevia. Poder Legislativo Federal Cámara de Diputados. CDMX, México, 13 p. http://www.cedrssa.gob.mx/files/b/13/92Estevia.pdf

[16] Ramírez, J.G. (2011) Paquete Tecnológico Estevia (Stevia rebaudiana) Establecimiento y mantenimiento. Paquete Tecnológico. Publicación Especial Núm. 1. Campo Experimental Mocochá. Instituto Nacional de Investigaciones Forestales, Agrícolas y Pecuarias, México, D.F., 22 p.

[17] Avilés, B.W.I., Moguel, O.Y.B. and Ramírez, J.G. (2013) Memorias del VII Simposio Internacional de Stevia (Ka'a He’ê). Centro de Investigación Regional Sureste del Instituto Nacional de Investigaciones Forestales, Agrícolas y Pecuarias (INIFAP), Mérida, Yucatán, 9-11 de Diciembre de 2013, 10 p.

[18] Polit, D.P. and Hungler, B.P. (1991) Investigación científica en Ciencias de la Salud. Nursing Research. Principies and Methods. Tr. Carlos Casacuberta Zaffaroni y Guillermina Feher. 3ra. ed., México, lnteramericana, México, D.F., 66 p.

[19] López, E.R., Uresti, G.J., Inurreta, A.D., Uresti, D.D., Ramírez, J.G. and May, L.C. (2013) Potencial Productivo de Stevia rebaudiana Bertoni, en los estados del Sur-Sureste de México. En: Memorias del VII Simposio Internacional de Stevia (Kà a Hẻ ê), Centro de Investigación Regional Sureste del Instituto Nacional de Investigaciones Forestales, Agrícolas y Pecuarias (INIFAP), Mérida, Yucatán.

[20] Ramírez, J.G., Avilés, B.W., Moguel, O.Y., Góngora, G.S. and May, L.C. (2012) Estevia (Stevia rebaudiana Bertoni), un cultivo con potencial productivo en México. Instituto Nacional de Investigaciones Forestales, Agrícolas y Pecuarias. Centro de 
Investigación Regional Sureste, Mérida, Yucatán, México. 88 p.

[21] Ramírez, J.G., Avilés, B.W., Moguel, O.Y. and Góngora, G.S. (2013) Informe Final del Proyecto: Validación, Desarrollo y Difusión de la Tecnologia en Estevia (Stevia rebaudiana Bertoni) bajo condiciones de riego en el Sur Sureste de México. Instituto Nacional de Investigaciones Forestales, Agrícolas y Pecuarias, Centro de Investigación Regional Sureste, Inédito, Mérida, Yucatán, México.

[22] Ramírez, J.G. and Moguel, O.Y. (2015) Stevia rebaudiana Bertoni, a Crop with a Productive, Sweetener and Medicinal Potential in Mexico. In: Betancur-Ancona, D. and Segura-Campos, M., Eds., Stevia rebaudiana: Chemical Composition, Uses and Health Promoting Aspects, Nova Science Publisher, Inc., New York, 1-24.

https://novapublishers.com/shop/stevia-rebaudiana-chemical-composition-uses-an d-health-promoting-aspects/

[23] Soria, R.J., Fernández, O.Y., Sotelo, R.E., Medina, G.G., May, L. and Ramírez, J.G. (2013) Pruebas de Adaptación y Zonas Potenciales para la Producción de Stevia (Stevia rebaudiana, Bertoni) en el estado de México. En: Memorias del VII Simposio Internacional de Stevia (Ka’a Hè ê), Centro de Investigación Regional Sureste del Instituto Nacional de Investigaciones Forestales, Agrícolas y Pecuarias (INIFAP), Mérida, Yucatán.

[24] Avilés, B.W.I., Moguel, O.Y.B. and Ramírez, J.G. (2013) Control de Maleza en el Establecimiento de Estevia (Stevia rebaudiana Bertoni), en Yucatán, Mexico. En: Memorias del VII Simposio Internacional de Stevia (Ka'a He'ê). Centro de Investigación Regional Sureste del Instituto Nacional de Investigaciones Forestales, Agrícolas y Pecuarias (INIFAP), Mérida, Yucatán.

[25] López, L.R., Ramírez, J.G., Nava, P.R., Ramírez, S.J. and Moguel, O.Y. (2013) Produccion de estevia (Stevia rebaudiana Bertoni) en suelos luvisoles de Tabasco, México. En: Memorias del VII Simposio Internacional de Stevia (Kả a Hẻ ê), Centro de Investigación Regional Sureste del Instituto Nacional de Investigaciones Forestales, Agrícolas y Pecuarias (INIFAP), Mérida, Yucatán.

[26] Góngora, G.S., Ramírez, J.G., May, L.C., Soria, R.J. and López-López, R. (2013) Análisis de inversión del cultivo de la estevia (Stevia rebaudiana Bertoni) en el Estado de Yucatán, México. En: Memorias del VII Simposio Internacional de Stevia (Kảa $H e ̉ e ̂)$. Centro de Investigación Regional Sureste del Instituto Nacional de Investigaciones Forestales, Agrícolas y Pecuarias (INIFAP), Mérida, Yucatán.

[27] May, L.C., Ramírez, J.G. and Góngora, G.S. (2013) Validación de la cosechadora mecánica en Stevia rebaudiana (Bertoni) en el estado de Quintana Roo. En: Memorias del VII Simposio Internacional de Stevia (Kảa He’ ê), Centro de Investigación Regional Sureste del Instituto Nacional de Investigaciones Forestales, Agrícolas y Pecuarias (INIFAP), Mérida, Yucatán.

[28] Ramírez, J.G., Moguel, O.Y. and May, L.C. (2013) Evaluación de la tecnología de estevia Stevia rebaudiana (Bertoni), en Yucatán, Mexico bajo condiciones de riego. En: Memorias del VII Simposio Internacional de Stevia (Kàa Hè ê), Centro de Investigación Regional Sureste del Instituto Nacional de Investigaciones Forestales, Agrícolas y Pecuarias (INIFAP), Mérida, Yucatán.

[29] Ramírez, S.J., Cano, G.A. and Ramírez, J.G. (2013) Macroelementos en suelos mecanizables de la Península de Yucatán y requerimientos nutrimentales de la Stevia rebaudiana Bertoni. En: Memorias del VII Simposio Internacional de Stevia (Kảa $H e ’ e ̂)$, Centro de Investigación Regional Sureste del Instituto Nacional de Investigaciones Forestales, Agrícolas y Pecuarias (INIFAP), Mérida, Yucatán.

[30] May, L.C., Ramírez, J.G. and Góngora, G.S. (2013) Respuesta del cultivo de Stevia rebaudiana (Bertoni) bajo diferentes dosis de fertilización en Yucatán. En: Memo- 
rias del VII Simposio Internacional de Stevia (Kảa Hẻ ê), Centro de Investigación Regional Sureste del Instituto Nacional de Investigaciones Forestales, Agrícolas y Pecuarias (INIFAP), Mérida, Yucatán.

[31] Moguel, O.Y., Ruiz, R.J., Ramírez, J.G., Avilés, B.W. and Betancur, A.D. (2013) Contenido de steviosido y rebaudiosido a en tres materiales de Stevia rebaudiana Bertoni cultivadas en el Sur-Sureste de Mexico. En: Memorias del VII Simposio Internacional de Stevia ( $\mathrm{Ka}$ a $\mathrm{He}$ ê), Centro de Investigación Regional Sureste del Instituto Nacional de Investigaciones Forestales, Agrícolas y Pecuarias (INIFAP), Mérida, Yucatán.

[32] Lozano, C.M.G. and Ramírez, J.G. (2016) Propagación de Stevia rebaudiana Bertoni con Enraizadores Biológicos. Instituto Nacional de Investigaciones Forestales, Agrícolas y Pecuarias. Centro de Investigación Regional Sureste, Campo Experimental Mocochá, Mérida, Yucatán, México, 28 p.

[33] Ramírez, J.G. (2014) Informe Final del Proyecto de Impulso a la Innovación: PRODUCCION DE PLANTINES DE STEVIA. Instituto Nacional de Investigaciones Forestales, Agrícolas y Pecuarias. Centro de Investigación Regional Sureste, Inédito, Mérida, Yucatán, México.

[34] Ramírez, J.G. (2016) Informe Final del Proyecto: MEJORAMIENTO GENETICO DEL CULTIVO DE STEVIA (Stevia rebaudiana Bertoni) PARA LA OBTENCIÓN DE VARIEDADES CLONALES MEXICANAS (Yucatán). Instituto Nacional de Investigaciones Forestales, Agrícolas y Pecuarias, Centro de Investigación Regional Sureste. Inédito, Mérida, Yucatán, México.

[35] Ramírez, J.G., Avilés, B.W., Moguel, O.Y. and Góngora, G.S. (2018) Informe Final del Proyecto: CARACTERIZACIÓN DE MATERIALES GENETICOS DE Stevia rebaudiana Bertoni. Instituto Nacional de Investigaciones Forestales, Agrícolas y Pecuarias, Centro de Investigación Regional Sureste, Inédito, Mérida, Yucatán, México.

[36] Lozano Contreras, M., Ramírez Jaramillo, G. and Moguel Ordóñez, Y. (2020) Ch'ujuk: Variedad clonal de 'estevia' como alternativa al cultivo masivo de Morita II para el Trópico de México. Revista Mexicana de Ciencias Agrícolas, 11, 2005-2010. https://doi.org/10.29312/remexca.v11i8.2018 